\title{
The gradual transformation of a weak but enduring regime: Contemporary French prostitution policy in transition (1946-2016)
}

\author{
Emily St.Denny \\ Public Policy Institute for Wales, Cardiff University, Cardiff, UK
}

This is an Author's Accepted Manuscript of an Article published in Modern and Contemporary France, 2017, copyright Taylor \& Francis, available online at: http://www.tandfonline.com/doi/full/10.1080/09639489.2017.1304902

\begin{abstract}
Historically, states have tended to opt for one of three prostitution policy regimes: prohibition; regulation; or the abolition of state regulation with a view to providing social support to the individuals involved. This is the approach France has espoused since 1960. Nevertheless, while the state has remained committed to abolitionism, the policies and laws adopted in the name of French abolitionism have varied considerably. This co-existence of stability and change challenges current assumptions of how policy regimes behave and evolve. This is because internal policy change suggests that the regime is weak, and weak regimes that experience strong political challenges are assumed to wither away or collapse. Consequently, this article presents the historical case study of contemporary French prostitution policy, and seeks to explain how and why this policy regime has changed the way it has since World War II. It describes the three phases that have contributed to the evolution of policy in this area, from sex workers' rights protests in the mid-1970s, to the introduction of a demand-side ban on prostitution in 2016. In doing so, it explains how strong commitment to policy ideas can help sustain and otherwise weak or ineffective policy regime.
\end{abstract}

Keywords: prostitution; sex work; institutionalism; gender; social policy 


\section{The gradual transformation of a weak but enduring regime: Contemporary French prostitution policy in transition (1946-2016)}

Immediately after World War II, France began to dismantle its system of state-regulated prostitution. First, it passed a law banning brothels in 1946. Then, in 1960, the compulsory medical and police registration of women in prostitution was discontinued. This date marks France's final transition from a regulationist approach to dealing with prostitution, to an 'abolitionist' one. Abolitionism originally referred to national prostitution policy frameworks based on the abolition of state regulations pertaining to prostitution. This approach seeks to distinguish itself from both regulationism and prohibitionism by considering those who sell sex as 'victims' and, consequently, by opting neither to organize prostitution, nor criminalise those involved. This stance is based, on the one hand, on punishing those who exploit the prostitution of others (eg. pimping or brothel-keeping), and, on the other, on providing social support to the 'victims' of prostitution. Consensual prostitution between independent adults, however, remains tacitly legal.

2016 therefore marked the seventieth anniversary of France's transition to abolitionism. Throughout this time, successive governments have remained committed to this model of prostitution policy. However, the laws and policies they have enacted in its name have varied considerably. Policies based on supporting 'victims' have been replaced by some that instead seek to jail them for appearing in public. Finally, the most recent reform, introduced in April 2016, saw the country adopt a de facto demand-side ban on prostitution based on client criminalization. This reform indicates a shift in what abolitionism means in France, from a policy model based on the abolition of state-regulated prostitution but which implicitly tolerates commercial sex, to one which seeks to 'abolish' prostitution entirely. Consequently, the trajectory of post-war French prostitution policy poses a policy paradox: while the country has claimed to remain abolitionist since 1960, the laws and programs adopted under the banner of French abolitionism today look very different from those adopted seventy years ago.

Theoretically, existing public policy scholarship has difficulties explaining how such a policy framework can appear to simultaneously persist and change. Empirically, this puzzle is of historical interest because it concerns whether France's current abolitionist framework can be considered an updated version of the policy model adopted at the eve of reconstruction, or instead represents a shift to an entirely new policy approach. This article therefore explores how and why French prostitution policy has changed the way it has since the end of the Second World War. It argues that France's abolitionist policy framework can be usefully conceptualized as a policy regime - a framework of institutions, ideas, and interests, which serves to coordinate public action on a single policy problem. Moreover, this regime has historically been plagued by weak policy implementation and a great deal of disagreement over what 'abolitionism' means. This has allowed policymakers to gradually reinterpret 'abolitionism' to suit their beliefs and interests, and led to contrasting policies being adopted under the auspices of a single regime. Drawing on archival research and documentary analysis, the article therefore unpicks how, even in the context of ineffective policy implementation, French policymakers' unwavering commitment to values and ideas associated with changing definitions of 'abolitionism' have allowed the regime to endure, while being gradually transformed. 


\section{The evolution of French abolitionism}

Between the $16^{\text {th }}$ and $18^{\text {th }}$ century, the French state was involved in strictly controlling prostitution, either through regulating brothels (maisons closes), or by prohibiting it outright (Maugère, 2009). In particular, fears concerning the role of prostitution in endangering the health of the country's soldiers during the revolutionary period (1789-1804) contributed to the development of a framework of 'managed tolerance' (Plumauzille 2016). This approach combined the strict regulation of brothels with the compulsory medical and police registration of women in prostitution (Corbin 1996, 9). At its apogee, towards the end of the century, this regulatory framework was internationally regarded as one of the most developed, and emulated as a result, earning it the title of 'French system' ('système français') (Limoncelli 2006, 35, 2010, 23; Mathieu 2013a, 25; Solé 1993, 23).

Nevertheless, in the context of a growing international advocacy movement calling for the abolition of state-regulated prostitution, the primacy of France's regulationist system began to erode during the inter-war period. Ultimately, the country began to abolish its regulatory framework immediately after the Second World War by banning brothels in metropolitan France April 1946. ${ }^{1}$ The timing of this path-departing reform has been the subject of considerable historical discussion. There is broad consensus that the outlawing of the maisons closes in 1946 was part of the national process of épuration (purification) that took place after the war, which was aimed at symbolically eliminating all people, practices, and institutions associated with the country's occupation by foreign powers during the conflict (Adler 1999, 51; Corbin 1996, 347; Maugère 2009, 162; Roberts 2010, 104). The close association of France's brothels with the German occupying army and, later, with American soldiers on leave, reinforced the perception of their institutions as indefensible and unpatriotic in the national psyche (Adler 1999, 51; Roberts 2010, 104).

1946, however, only marks a partial transition away from regulationism. This is because, while brothels were shut down, women in prostitution continued to be registered with the authorities and medically monitored, and brothels in France's colonies remained regulated until 1960, when the country signed the 1949 United Nations convention on the "Suppression of the Traffic in Persons and of the Exploitation of the Prostitution of Others". This treaty sets out the main principles of abolitionism (Mathieu 2012, 204). In particular, it requires signatories to outlaw the exploitation of prostitution by others, but also considers prostitution as a private matter which should not involve the registration and medical monitoring of individuals. By ratifying the convention, France committed itself to repealing any remaining regulation, and the country's two-step transition from regulationism to abolition was concluded.

To this day, the 1949 UN treaty remains the primary legal reference for public action concerning prostitution in France (Mathieu 2012, 204). The convention also constitutes the normative foundation of French abolitionism. It enshrines a conception of prostitution as a blight on society, and depicts individuals involved in prostitution - which it primarily considers to be women and children - inherently as victims. ${ }^{2}$ In keeping with the 'spirit' of this abolitionist vision, French abolitionists believe prostitution to be a social scourge and represent the gendered exploitation of women, they also tend to consider those involved to be

\footnotetext{
${ }^{1}$ Loi n ${ }^{\circ} 46-685$ dite Marthe Richard du 13 avril 1946.

${ }^{2}$ Preamble and article 1 of the Convention for the Suppression of the Traffic in Persons and of the Exploitation of the Prostitution of Others, approved by the United Nations General Assembly on 2 December 1949, entry into force on 25 July 1951.
} 
psychologically mal-adjusted victims of unscrupulous pimps or an abusive past (Bugnon 2010, 147; also see Allwood 2006, 58; Mathieu 2012, 204, 2013a, 28). As a result, the legalisation or regulation of prostitution as a form of labour is anathema to French abolitionists, who equate it with the state's formal endorsement of a system of violence (Allwood 2008, 67; Mathieu 2004, 158).

After its ratification, the norms and principles concerning the nature of prostitution and what ought to be done set out in the treaty were transposed into French law. Together, they served to construct a policy framework based on two 'pillars' (Allwood 2006, 51): the criminalization of the exploitation of prostitution, which includes the banning of brothels, and the punishment of anybody who is seen to profit from, encourage, organize, or facilitate the prostitution of another; and the provision of social support to the 'victims' of prostitution (Bugnon 2010, 144; Mathieu 2004, 155). These two pillars have formed the basis for the abolitionist French state's approach to dealing with prostitution ever since. However, despite the continued dominance of this broad framework, the actual laws and policies implemented to enact its two core principles have varied considerably over the last fifty years (Mathieu 2012, 203).

The trajectory of contemporary French prostitution policy since 1960 therefore features a concurrence of stability and change. The issue of prostitution has not mobilized constant political attention throughout the period (cf. Mazur, 2004). During these absences from the political agenda, policy remained unchanged, giving the impression of a largely stable policy path. Nevertheless, the issue has sporadically resurfaced to generate heated policy debates. These infrequent 'punctuations' have often led to either the reevaluation or reform of existing policy. At first glance, then, the historical path of French abolitionism reflects what policy scholars refer to as a 'punctuated equilibrium': a principally steady developmental path, intermittently interrupted by sudden and rapid moments of change (Baumgartner, Jones, and Mortensen 2014, 59). Between 1960 and 2016, three distinct policy phases, prompted by such punctuations, can be distinguished.

\section{Phase one (1960-1980): Protests and discontent}

First, for a decade following the ratification of the UN treaty, the issue of prostitution was noticeably absent from the political agenda (Mazur 2004, 127). During this time, social support to individuals in prostitution pledged by the state upon ratifying the $1949 \mathrm{UN}$ convention failed to materialize (Allwood 2006, 51; Mathieu 2004, 155, 2012, 205; Mazur 2004, 124; Solé 1993, 18). This was partly due to a lack of interest on behalf of the administrative agents, particularly préfets (prefects), responsible for ensuring each département complied the new national guidance on this issue, as well as the gradual reduction in state subsidies earmarked for this purpose (Mathieu 2013a). Consequently, abolitionist charities such as the Mouvement du Nid (MDN) increasingly stepped in to provide help and support services to women in prostitution, as long as they committed to exiting $(2013 \mathrm{a}, 47,77)$. Over time, this led to a self-reinforcing process whereby, on the one hand, local authorities were comforted in their belief there was no need to duplicate services delivered by the voluntary sector and, on the other, abolitionist organisations gained ever-more control and legitimacy over shaping and delivering dedicated social services to individuals in prostitution.

It is in this context that the issue of prostitution reemerged as a policy problem in the early 1970s. At that time, the government ordered a clampdown on prostitution after the discovery of a corruption scandal linking prominent public officials to the running of brothels (Mazur $2004,127)$. This led to women in prostitution being increasingly arrested and fined for offenses relating to solicitation and pimping (Mathieu 2001, 38). Conversely, collusion between the 
police and certain pimps and hotel-based brothel keepers who were used as informants in exchange for protection remained widespread (cf. Le Monde, 20 and 21 August, 1972).

Thus, by the early 1970s, France's abolitionist policy framework had begun to show signs of being inconsistently and haphazardly applied. The repressive measures it affirmed where meant to punish those who exploited the prostitution of others were primarily used not against pimps but against women in prostitution themselves. Furthermore, the state had largely divested itself of its responsibility to deliver the social policies that were intended to give substance to the protective 'spirit' of abolitionism, leaving the third sector to fill the gap. As a result, the daily existence of women in prostitution was characterized by insecurity and precarity. These conditions were epitomized and exacerbated when, between 1971 and 1974, several women involved in prostitution were brutally murdered and the police failed to effectively investigate (Corbin 1996; Mathieu 2001).

To protest against police persecution and the state's lack of concern for their welfare, a group of women in prostitution, assisted by certain religious, feminist and abolitionist organisations, mobilized in 1975 and began occupying churches in a number of French cities (Mathieu 2001). The movement's aims were to draw attention to the injustices and insecurity faced by women in prostitution, to impel the government to discontinue its policy of harassment, and to secure basic social rights for individuals in prostitution (Mathieu 2001, 42). Embarrassed by this incongruous protest, the government commissioned an evaluation of the country's prostitution policy framework. The final report was highly critical of the existing prostitution policy framework. It argued that, while abolitionism was the best approach in theory, its application in France was ineffectual and, in some cases, harmful to the very people it sought to protect women in prostitution (Pinot 1975, 9, 12). Nevertheless, in part because it challenged some of the framework's core tenets and, in particular, called for the decriminalization of soliciting, the report was met with little political interest, 'buried', and quickly forgotten (Mathieu 2001, 95).

In the years following the occupation of Saint-Nizier, the issue of prostitution largely fell off the political radar. The unseemly protest having been quashed, the government was free to turn its attention to other issues and the sex workers' rights movement quickly lost focus and disbanded (Mathieu 2001, 88). The campaign regained momentum in 1980 during the highprofile trial of twelve pimps running a large-scale prostitution ring in Grenoble (cf. Solé 1993). The 'procès de Grenoble' ('Grenoble trial') was particular in that it was brought about by women in prostitution pressing charges against their pimps. It drew intense media and public attention not only to the daily inequities faced by women in prostitution, but also to the existence of a large transnational network of exploitation operating across the French and Italian border. Thus, while no formal changes to policy were enacted as a result of the events of 1975 and 1980, two new trends emerged. First, the topic of prostitution was no longer routinely ignored by the media and the wider public. Secondly, aided by the government and media's reaction to these events, a picture of prostitution in France began to emerge which tightly linked it to exploitation and organized crime.

\section{Phase two (1981-2000): AIDS as a policy crisis}

Despite the media attention generated by the 'procès de Grenoble' in the summer of 1980, the issue of prostitution only truly reemerged on the political agenda the following years as a result of growing public and political fears over its perceived role in spreading AIDS (Mathieu 2000, 7; Mazur 2004, 126). In France, the politicization of AIDS as a high-priority policy issue, rather than a health issue to be dealt with by doctors and epidemiologists, happened relatively late compared, for example, with the United States and United Kingdom (Steffen 1993: 240). The 
socialist government initially shied away from direct involvement in the issue until the mid1980s. This was due to a reluctance to weigh in on an unfamiliar problem that was still perceived as 'marginal', as well as the fear of alienating voters as a consequence of the issue's link with homosexuality (Thiaudière and Pinell 2002, 78-79).

By 1986, however, AIDS and the dominant representations associated with it had become an everyday 'element of social life' (Herzlich and Pierret 1988, 1111; Solé 1996, 579). As a result, political actors could no longer refuse to speak up on the issue, lest they be accused of showing insufficient concern over how to address the problem (Favre 1993: 11). This contributed to the rise of heated polemics. On the one hand, the far-right Front National (FN - National Front) framed the disease as a threat to France's physical, moral, and racial health (Mathieu 2000: 79; Pratt 1998: 276; Thiaudière and Pinell 2002, 93). On the other hand, left-wing political actors criticized the double-victimisation of those belonging to lower socio-economic groups who were not only ill, but were also disproportionately affected by the negative social and economic impacts of the disease, including stigma and unemployment (Bacot 1991: 95).

It is in this context of conflict and contestation that the topic of prostitution resurfaced on the policy agenda (de Busscher and Pinell 1996, 33; David 2006, 115-116; Mathieu 2000, 79, 2013b, 7; Mazur 2004, 131-132; Pinell 2002, 16; Pollak 1992, 26). This was due to the growing popular belief that individuals in prostitution were responsible for spreading AIDS to the general population via 'unwitting' male clients (eg. Barzach in Le Monde, 8 June, 1990; Le Monde, 27 October, 1989, 16). This led to a high profile political debate over the possibility and desirability of returning to a regulationist system. This debate was prompted by the declaration by former Health Minister, Michèle Barzach, that "the question of re-opening staterun bordellos" must be reexamined in order to protect public health (Le Monde, 8 June, 1990). This suggestion was quickly opposed by a "broad coalition" of policy and influential civil society actors with strong anti-regulationist views, and Barzach quickly recanted (Mazur 2004, 133).

Once again, this episode did not lead to any formal policy changes. It did, however, have two lasting effects on the way prostitution policy would subsequently be debated in France. First, the intensity of the opposition to Barzach's comments served to henceforth and definitively halt any further consideration of a return to regulation in France (Mazur 2004, 133). In so doing, the episode ensured that abolitionism was once and for all reaffirmed as the only acceptable and appropriate approach for the French state to take on matters concerning prostitution - a hegemony the framework enjoys to this day. Secondly, the ascendency of public health concerns from the late 1980s onwards, coupled with the lack of formal government involvement in delivering dedicated health and social services to individuals in prostitution, contributed to the rise of new policy actors that challenged the monopoly of social workers and abolitionist charities as a competing source of social and health services to individuals in prostitution (Mathieu 2004, 155, 2012, 205). These organisations privileged education and harm reduction to address the immediate health and safety needs of individuals in prostitution, rather than imposing exit and rehabilitation. This operating procedure contributed to promoting new representations of individuals in prostitution as capable agents directly at odds with traditional abolitionist conceptions of them as victims (Mathieu 2004, 155).

\section{Phase three (1989-2016): Redefining French abolitionism in a globalized world}

The third phase during which the institutional trajectory of French abolitionism was gradually altered began with the fall of the Communist bloc in 1989, and the subsequent opening of borders between European states. These global transformations had a profound impact on the 
modalities of commercial sex in France (cf. Handman and Mossuz-Lavau 2005). The number of foreign women on the streets of French cities grew considerably, and their visibility, youth and appearance led to public outcry (Allwood 2003, 206; Mathieu 2011, 2012, 206). Moreover, these women were invariably considered to be under the control of large transnational criminal networks (Mathieu 2012, 206). The increased - and increasingly problematic - visibility of prostitution on streets and in residential areas was perceived as a security issue by residents who exhorted policymakers to provide a rapid solution (Guienne 2006; Mathieu 2012, 206). Moreover, the public and policymakers drew strong links between this new form of prostitution and transnational organized crime and trafficking for the purposes of sexual exploitation (Mathieu 2013b, 15-16; Maugère 2009, 226). As a result, the issue of prostitution was once again politicised (Allwood 2003; Mathieu 2011, 2012, 207). It is in this context, dominated by a 'law and order discourse' that the 2002 domestic security bill (proposition de loi pour la sécurité intérieure - PLSI) ${ }^{3}$, which included anti-soliciting measures aimed at repressing visible prostitution, found support (Allwood 2003, 205).

The subsequent adoption of the loi pour la sécurité intérieure (LSI) in 2003 has been a key focal point of recent scholarship on contemporary French prostitution policy because it appears to contrast with previous policies adopted under the banner of abolitionism (cf. Allwood 2003; Deschamps 2005; Mainsant 2013; Mathieu 2011, 2012; Vernier 2005). In particular, the law constructed prostitution as a law-and-order and domestic security issue and, as a result, shifted the policy emphasis away from the provision of social support and towards the implementation of strict anti-soliciting measures. Most notably, the LSI reclassified soliciting as a major offence and reintroduced the offence of 'passive soliciting' ('racolage passif') - that is to say the act of adopting an attitude or posture, even passive, with the aim of inciting another to debauchery - which had been removed from French law in the 1992 reform of the penal code. The new law also included measures to deport foreigners guilty of prostitution.

The reason why these measures were allowed to pass in a context where abolitionism remained the state's only accepted approach to dealing with prostitution is because they were successfully framed as compatible with it. Indeed, right-wing politicians in favour of the bill's anti-prostitution measures sought to highlight two ways in which they 'fitted' with the existing abolitionist framework and its underpinning norms. Firstly, they reappropriated the construction of individuals in prostitution as 'victims' from the abolitionist repertoire. This was facilitated by the conflation of prostitution and trafficking. On the one hand, foreign women in prostitution were depicted as guilty of many things, such as soliciting, disrupting public order, or entering the country illegally, and therefore represented as deserving of expulsion. On the other hand, these same women were also portrayed as vulnerable victims of unscrupulous traffickers and pimps. This enabled proponents of the LSI to present women in prostitution as simultaneously victims and criminals, justifying the use of punitive measures to 'save' them from exploitation (Jaksic 2016). The redeployment of this 'victim' discourse to justify their policy aims is evident, for example, when the Minister of the Interior, Nicolas Sarkozy, who had introduced the bill, asserted that: "[...] we have not created an offence with a view to punishing these unhappy women who, it cannot be denied, are more often victims than culprits. If we have created an office it is, on the contrary, to protect them [...]"4 (in JORF, 13 November 2002, n.p.).

\footnotetext{
${ }^{3}$ Loi n ${ }^{\circ} 2003-239$ du 18 mars 2003 pour la sécurité intérieure.

4 “[...] nous n'avons pas créé un délit dans l'optique de punir des malheureuses qui, c'est vrai, sont plus souvent victimes que coupables. Si nous avons créé un délit, c'est, au contraire, pour les protéger [...]”
} 
Secondly, the Government emphasized the way the bill was compatible with the abolitionist regime's existing social and criminal aspirations. Thus, the repression of foreign and streetbased prostitution was presented as both a social service to 'victims' and a means of fighting against their exploitation. The recriminalisation of passive soliciting was also primarily portrayed as a means of making it more difficult for pimps and traffickers to profit from prostitution, rather than a way to punish the 'victims'. Thus, Sarkozy explains that, "[b]y penalizing soliciting, we penalize those who profit from soliciting by putting girls on the streets [...] Who benefits when we make it impossible to exhibit these unhappy women? Precisely the unhappy women we will be liberating from their torturers' grasp"5 (in JORF, 22 January, 2003, n.p.). Similarly, the repatriation of foreigners guilty of soliciting on French streets was framed as a humanitarian service:

to me, it seems more than normal to expel prostitutes who do not speak a work of French, who have only been in our country for a few short months of a few weeks, and who we can deliver from networks by accompanying them back to the countries where they were born $[\ldots]^{6}$ (Sarkozy in JORF, 13 November, 2002, n.p.).

This framing served to foreground the social value of measures traditionally associated with criminal justice, such as police custody and deportation, thereby firmly placing them within the abolitionist state's obligation to provide social assistance to individuals in prostitution (Maugère 2009, 305).

Ultimately, by portraying these measures as 'humanitarian' efforts to rescue vulnerable women and facilitate their return home, the LSI was made to appear as if it did not contravene the norms underpinning the traditional French abolitionist framework (Mathieu 2012, 207). Nevertheless, because it appeared to subordinate the core abolitionist principle of victim welfare to the objective of cleaning up the street, the LSI continues to be apprehended as an anomaly in the history of contemporary French prostitution policy in the literature. For this reason, Allwood argues that the LSI constitutes a shift of policy focus by "launching a war not on prostitution, but on prostitutes" $(2003 \mathrm{a}, 206)$. In this way, while policy advocates may have constructed the LSI as compatible with French abolitionism, it continues to stand out as an exceptional reform because of its predicated on the paradoxical conceptualization of individuals in prostitution as both victims and criminals (Mathieu 2012, 207).

However, within two years of its implementation, evaluations of the LSI began to highlight its ineffectiveness. Some condemned it for failing to make prostitution disappear, others denounced the negative impact it was believed to have on the safety and wellbeing of individuals in prostitution (e.g. Citoyens-justice-police 2006; Mossuz-Lavau 2007; Vernier 2005). This criticism only increased over time and opened a new window of opportunity for policymakers to challenge the existing abolitionist framework and propose reforms. By 2010, there was broad political agreement that the LSI had failed and was contributing to pushing prostitution further underground (eg. CNCDH 2010; CNS 2010). That year, a Parliamentary committee was created to review the law and propose alternatives. The committee released its report in 2011. In it, it found the LSI's anti-soliciting measures to be ineffective and possibly

\footnotetext{
5 “En pénalisant le racoage, on pénalise ceux qui profitent du racolage parce qu'ils mettent des filles sur le trottoir. [...] À qui rend-on service quand on rend impossible l'exposition de ces malheureuses? À ces malheureuses que l'on va libérer du joug de leurs tortionnaires."

6 “il me paraît plus que normal de procéder à l'expulsion de prostituées qui ne parlent pas un mot de français, qui ne sont que depuis quelques mois ou quelques semaines présentes sur notre territoire et que l'on peut faire échapper aux réseaux en les raccompagnant dans le peus où elles sont nées [...]."
} 
detrimental to the welfare of individuals in prostitution (Geoffroy 2011, 112-115). It also recommended that the LSI's ban on passive soliciting be lifted, and that a law criminalizing the purchase of sex be adopted instead (Geoffroy 2011, 321-326).

Over the following years, support for client criminalization grew, bolstered by the emergence of a broad coalition of abolitionist activists, and feminist and left-wing politicians (Mathieu, 2013a: 240). This coalition portrayed client criminalization as a policy 'panacea': a single and overarching solution to the complex problem of prostitution (Mathieu 2013a, 241, 2013b, 17). Specifically, it would allow the complete prohibition of prostitution, without criminalizing the 'victims' (Mathieu 2013a, 241). This option nevertheless met with considerable resistance on both the left and the right. Sex workers' rights activists, certain community health groups, and many Green politicians denounced it as yet another policy that endangered the welfare of individuals in prostitution by forcing them to operate in the shadows (eg. Benbassa in Pacione 2014; Cavard 2013; Le Monde, 12 June, 2015; Schaffauser 2013). Conservative politicians also widely opposed the proposal, finding it unfathomable that clients be punished while individuals in prostitution would no longer be arrested for solicitation (eg. Goujon in JORF, 29 November, 2013, 12439).

A bill seeking to comprehensively reform France's abolitionist policy regime and introduce client criminalization was introduced in the National Assembly in October 2013. As a result of the strong antagonisms between abolitionists and those who either wished to criminalise or decriminalize prostitution, the bill became the subject of a lengthy and conflictual debate, both inside and outside of the Parliament. It was nevertheless ultimately adopted on April $6^{\text {th }} 2016$ after having been blocked three times by the Senate. ${ }^{7}$ Among other things, the final law repealed the LSI's anti-soliciting measures, grants temporary residency to foreign victims of exploitation, and introduces a new offence criminalizing the clients of prostitution. This law officially came into force on April $13^{\text {th }} 2016$, seventy years to the day after the adoption of the law banning brothels which sounded the death knoll of the système français. The introduction of this reform marks the final transformation of French abolitionism from a framework based on the abolition of the state regulation of prostitution, to one that seeks the abolition of prostitution itself by means of a demand-side ban.

\section{The gradual transformation of French abolitionism}

Historical analysis of contemporary French prostitution policy reveals the considerable variation in laws and programs enacted in the name of abolitionism over the last seventy years. While the State has remained committed to enacting an abolitionist approach to prostitution throughout the period, these internal transformations belie the notion that this policy area has remained stable during this time. This historical trajectory challenges traditional accounts of policy change in two ways. First, it contradicts representations of the trajectory of contemporary French prostitution policy as a 'punctuated equilibrium'. The nature of the changes experienced by the French abolitionist framework has not been sudden and radical. Rather small adjustments have incrementally accrued to modify it from a framework based on the abolition of state-regulated prostitution to one that seeks the complete abolition of prostitution itself. Second, the evolution of this policy area challenges current assumptions

\footnotetext{
${ }^{7}$ Loi $n^{\circ} 2016-444$ du 13 avril 2016 visant à renforcer la lutte contre le système prostitutionnel et à accompagner les personnes prostituées
} 
linking the strength of a policy framework - as measured by its perceived capacity to deliver on expected results - to its durability.

The main reason behind difficulties accurately describing and explaining the nature of change in this policy area since World War II is a lack of agreement over what, exactly, is meant by French 'prostitution policy' and 'abolitionism'. The key to understanding this historical trajectory therefore hinges on clearly conceptualizing and defining these terms. Broadly speaking, prostitution policy refers to courses of action taken by governments with regards to prostitution. 'Abolitionism' refers to one of three historically prevalent approaches states have adopted with regards to prostitution policy. These different approaches reflect different strongly held and often clashing beliefs concerning what prostitution is, and what the state ought to do about it, if anything. Until the $19^{\text {th }}$ century, states primarily opted to either regulate or prohibit prostitution. Prohibitionism outlaws prostitution by criminalizing all parties involved (pimps, clients, and those who sell sexual services). This approach tends to be underpinned by arguments concerning the need to protect public and social morality (Thukral 2006, 369). Conversely, regulationism, broadly refers to frameworks where the state is involved in organizing prostitution. Regulationism has historically been based on the state's desire to control women in prostitution in a putative bid to curb the spread of venereal diseases and protect public morality (Kilvington, Day, and Ward 2001, 79; Limoncelli 2006, 35-36; Mathieu 2014, 291-292).

From the late $19^{\text {th }}$ century onwards, however, a growing number of Western European states opted to implement an abolitionist prostitution policy framework (Limoncelli 2006). Originally abolitionism denotes an international movement seeking the abolition of the state regulation of prostitution (Mathieu, 2014: 292). This is because abolitionists considered regulatory laws and policies to represent the state's endorsement of women's sexual exploitation (Limoncelli 2006, 36; Maugère 2009, 186). Furthermore, they believe women in prostitution to be victims - either of exploitation, economic coercion, or personal hardship. Consequently, they campaign for the provision of social support to 'victims', and advocate the criminalisation of all those who profit from, exploit, encourage, or facilitate the prostitution of another (cf. Danna 2007, 7).

Over the last century, new national models of prostitution policy have emerged. New Zealand, for example, has decriminalized 'voluntary' prostitution without reintroducing a fully-fledged regulationist framework, on the basis that traditional state-licensed brothels have often exploited sex workers' labour (Abel and Fitzgerald 2010, 6). Conversely, in 1999, Sweden pioneered a 'new' or neo-abolitionism, aimed at abolishing prostitution entirely by criminalizing the purchase of sex (Skilbrei and Holmström 2011, 13). Nevertheless, what all these approaches - new and old - have in common, is that they represent policy regimes: overarching frameworks that integrate institutions, actors, ideas, and interests in order to address a particular policy problem (May and Jochim 2013, 427; May, Jochim, and Sapotichne 2011, 290-291).

Policy regimes feature two salient dimensions: their strength and their durability. A regime's strength refers to its ability to coordinate the action of different political actors, often with different ideas and interests, in order to achieve a common goal (May, Jochim, and Sapotichne 2011, 290). Thus, strength is a function of the cohesiveness of the ideas, interests and institutions that comprise a regime. Durability refers instead to a regime's capacity to sustain itself over time (Jochim and May 2010, 317). The relationship between these two dimensions is complex: not all strong regimes endure (for example those upset by unpredicted political 
crises), and not all weak regimes wither away, especially if there is no viable alternative to replace them with (Jochim and May 2010, 317).

Subsequently, the assumption is that, in the context of strong political efforts to overthrow it, a regime must necessarily be strong in order to sustain itself over time. For this reason, the French abolitionist regime presents an interesting puzzle: it is weak, or 'anemic', yet endures, even during periods when there is strong political competition to overthrow it. The regime's weakness is denoted by the policy variation that has characterised its development. Indeed, internal variation suggests an inability to foster cohesive policy action, reinforce shared policy goals, or mobilize support for a single clear policy objective.

At its core, the endurance of French abolitionism challenges assumptions that a regime's strength is a unidimensional property, with regimes ranging from 'strong' to 'anemic'. Instead, it suggests that a regime can simultaneously feature elements of strength and weakness. In this case, the regime features elements of institutional weakness but ideational strength. The regime's institutional weakness can be inferred from the ineffective and inconsistent application of its two policy 'pillars'. On the one hand, the state has historically divested itself of its statutory duty to provide social support to individuals in prostitution, delegating this task to chronically under-funded third sector organisations. On the other hand, it has been inconsistent in its approach to criminalizing the exploitation of prostitution, often punishing women in prostitution or their legitimate partners rather than focusing on pimps and brothelkeepers (Mathieu 2001: 41). At the same time, however, the regime clearly demonstrates considerable ideational strength. Specifically, key state actors have remained firmly committed to the ideas, values, and causal beliefs associated with abolitionism, and, in particular, the conception of women in prostitution as 'victims'. In this sense, since its adoption in 1960, abolitionism has retained its position as a dominant policy 'orthodoxy' in France: a broad framework of ideas and values that actors remain collectively committed to and which suppresses the emergence of any alternative (Legro 2000, 420).

The combination of a weak institutional framework and strong normative and ideational support has led to the regime's variable and incremental transformation. Perceptions of policy ineffectiveness in practice have periodically opened windows of opportunity for reform. However, continued support for the goals and values of abolitionism in principle have meant any reform proposal have had to be persuasively framed as compatible with the regime's core norms in order to be adopted. This was the case, for example, with the LSI. Substantively, the LSI appears to be an 'exceptional' reform, one which led to the criminalization of individuals in prostitution in a context where abolitionism is supposed to preclude this. The reason it was nevertheless introduced under the banner of abolitionism is because proponents framed it as compatible with abolitionist norms: victims would be arrested 'for their own good' (Allwood 2006, 56; Deschamps 2008, 106; Mathieu 2012, 207).

Overall, it has been possible for disparate policies to be slotted into the French abolitionist framework because there has never been consistent or definitive agreement over what 'abolitionism' means in France, even among its supporters (Mathieu 2013a, 216). Two interpretations of abolitionism in particular have always coexisted in France: one which presents it as a movement that merely seeks the abolition of state regulation, and another which believes it to be an ongoing struggle to abolish prostitution itself, first by dismantling state regulation, and then by disincentivising the sale and purchase of sexual services (Maffesoli 2008,37 ). As a consequence of this ambiguity, political actors have been able to gradually adapt the meaning of abolitionism to accommodate new perceived policy problems and 
preferences. This suggests that, just like social movements, policy regimes are not necessarily the same when considered at different points in their history, even if their name persists (cf. D'Anieri, Ernst, and Kier 1990; Gusfield 1963).

The introduction of a new demand-side ban on prostitution in France marks the conversion of a traditional abolitionist regime based on the abolition of state-regulated prostitution, to a neoabolitionist one that actively seeks to eradicate prostitution entirely (cf. Béland 2007, 22, 2010, 620; Mahoney and Thelen 2010, 16; Rocco and Thurston 2014, 40; Shpaizman 2014, 1039; Streeck and Thelen 2005, 26; Thelen 2004, 36; Vogel 2005, 145). This transition has been gradual and incremental, rather than swift and radical. Instead of a new policy regime being introduced wholesale, the original regime has been redirected towards a revised objective. Whether or not the recent adoption of a demand-side ban on prostitution represents the shift from one regime to an entirely new one remains a matter of interpretation. It depends on whether abolitionism is defined historically as a policy approach that merely seeks to abolish state regulation and encourage exit and rehabilitation, or whether it is defined more broadly as a movement that has always intended, in time, to make prostitution disappear completely. Nonetheless, by ending the tolerance of prostitution between consenting adults, the new law represents the association of very different ideas and policies with abolitionism than those originally introduced after the ratification of the 1949 UN convention.

\section{Conclusion}

After World War II, France began to dismantle its notorious system of regulated prostitution. By 1960 it had erected a two 'pillared' abolitionist framework which sought to criminalize the exploitation of prostitution and provide social support to those selling sex. Over the last seventy years, however, the enactment of these principles has been inconsistent and, in many cases, ineffective. Moreover, the laws and policies implemented to give substance to France's abolitionist approach have varied considerably, with weakly applied preventative and rehabilitative policies being superseded by punitive anti-solicitation laws, and, more recently, the introduction of client criminalization.

The evolution of contemporary French prostitution policy therefore features elements of both stability and change: while the state has remained steadfast in its commitment to abolitionism, the laws adopted in its name have changed. Three periods of change can be distinguished from this historical trajectory. First, discontent over the perceived harassment of women in prostitution in the mid-1970s highlighted the failure of the state to fully implement the ambition abolitionist framework it set out after ratifying the $1949 \mathrm{UN}$ convention, and gave rise to a nascent sex workers' rights movement. Then, fraught debates over the role of prostitution in spreading AIDS in the 1980s contributed to definitively sidelining a return to regulationism. Finally, the rise of street-based prostitution in the 1990s led to the exceptional side-stepping of traditional abolitionist values in a bid to cleanse the streets of visible foreign prostitution. The failure of this last policy opened a window of opportunity for abolitionists to reassert the relevance of their ideas. As a result, France's prostitution policy framework was converted into a neo-abolitionist regime which seeks to go beyond the abolition of state regulation and achieve the abolition of prostitution itself.

In order to understand how such a framework can simultaneously endure and change, it is necessary to understand its nature as a policy 'regime': a framework which draws together actors, ideas, and institutions to address a particular policy problem. In this regard, the French 
abolitionist regime stands out as a weak regime that endures despite the odds. It has persisted because, in spite of its poor record of policy performance, it has been increasingly supported by a broad coalition of state and third sector actors. While this coalition may not agree on the details of what abolitionism means, it nevertheless agrees that it is the only acceptable stance for the French state to adopt on the issue. Consequently, ambiguity over the ultimate meaning of abolitionism has allowed policymakers to gradually introduce new interpretations and policy goals. Ultimately, the newest interpretation of France's post-war prostitution policy framework has seen it transformed into a neo-abolitionist regime that seeks to eradicate prostitution entirely. This conversion marks the latest chapter in the gradual and incremental transformation of this anemic but enduring regime.

\section{Acknowledgements:}

The author wishes to thank Gill Allwood and Chris Reynolds, as well as an anonymous reviewer, for comments on previous drafts. Thanks also to the Association for the Study of Modern and Contemporary France for awarded the essay on which this article is based the 2016 prize for best postgraduate paper.

\section{Bibliography}

Abel, Gillian, and Lisa Fitzgerald. 2010. "Introduction." In Taking the crime out of sex work: New Zealand Sex Workers Fight for decriminalisation, edited by Gillian Abel and Lisa Fitzgerald, 1-23. Bristol: Policy Press.

Adler, Karen H. 1999. "Reading national identity: Gender and 'prostitution' during the Occupation." Modern and Contemporary France 7(1): 47-57.

Allwood, Gill. 2003. "Sarkozy's Domestic Security Bill: war on prostitutes not on prostitution?" Modern and Contemporary France 11(2): 205-212.

Allwood, Gill. 2006. "Prostitution in France." In International Approaches to Prostitution: Law and Policy in Europe and Asia, edited by Geetanjali Gangoli and Nicole Westmarland, 45-66. Bristol: The Policy Press.

Bacot, Paul. 1991. "Une représentation politique du sida: quelques modes discursifs au PCF." Médecine, Santé, Politique 26(1): 85-103.

Baumgartner, Frank R., Bryan D. Jones, and Peter B. Mortensen. 2014. "Punctuated Equilibrum Theory: Explaining Stability and Change in Public Policymaking." In Theories of the Policy Process, edited by Paul A. Sabatier and Christopher M. Weible, 59-103. $3^{\text {rd }}$ ed. Boulder, CO: Westview press.

Béland, Daniel. 2007. "Ideas and institutional change in social security: Conversion, layering, and Policy Drift.” Social Science Quarterly 88(1): 20-38.

Bugnon, Caroline. 2010. "L'encadrement de la prostitution par le droit, reflet d'un ordre juridique insaisissable." In Le traitement juridique du sexe, edited by Guillaume Delmas, Sarah-Marie Maffesoli and Sébastien Robbe, 143-168. Paris: L'Harmattan.

Cavard, Christophe. 2013a. "Prostitution: la proposition de loi qui divise les partis." Le Nouvel $\begin{array}{lllll}\text { Observateur, } & 29 & \text { November. Accessed } 14 & \text { December } 2014 .\end{array}$ 
http://tempsreel.nouvelobs.com/politique/20131128.OBS7515/prostitution-la-proposition-deloi-qui-divise-les-partis.html

Citoyens - Justice - Police. 2006. De Nouvelles Zones de Non Droit: Des prostituées face à l'arbitraire policier. Paris: Commission nationale sur les rapports entre les citoyens et les forces de sécurité, sur le contrôle et le traitement de ces rapports par l'institution judiciaire.

Commission national consultative des droits de l'homme (CNCDH). 2010. Avis sur la traite et l'exploitation des êtres humains en France. Paris: CNCDH.

Conseil National du Sida (CNS). 2010. VIH et commerce du sexe. Garantir l'accès universal à la prévention et aux soins. Conseil National du Sida: Paris.

Corbin, Alain. 1996. Women for Hire: Prostitution and Sexuality in France After 1850. Translated by Alan Sheridan. Cambridge, MA: Harvard University Press.

Couratin, Sébastien. 2013. "Prostitution : les quatre députés UMP euréliens ont tous voté contre le projet de loi." L'Écho Républicain, 5 December. Accessed 14 December 2014. http://www.lechorepublicain.fr/eure-et-loir/actualite/2013/12/05/prostitution-les-quatre-

deputes-ump-eureliens-ont-tous-vote-contre-le-projet-de-loi_1790485.html

D’Anieri, Paul, Claire Ernst, and Elizabeth Kier. 1990. "New Social Movements in Historical Perspective." Comparative Politics 22(4): 445-458.

Danna, Daniela. 2007. "Introduction." In Prostitution and Public Life in Four European Capitals, edited by Daniela Danna, 1-9. Rome: Carocci.

Deschamps, Catherine. 2005. "Mobilisations parisiennes des prostitué(e)s." In La Prostitution à Paris, edited by Marie-Elisabeth Handman and Janine Mossuz-Lavau, 91-120. Paris: Éditions de la Martinière.

Geoffroy, Guy. 2011. Rapport d'information déposé par la Commission des lois constitutionnelles, de la législation et de l'administration générale de la République, en conclusion des travaux d'une mission d'information sur la prostitution en France. Paris: Assemblée nationale.

Guienne, Véronique. 2006. "Politiques problématiques pour femmes publiques." In Action publique et prostitution, edited by Jean Danet and Véronique Guienne, 81-98. UHB Rennes 2: Presses Universitaires de Rennes.

Gusfield, Joseph R. 1963. Symbolic Crusade, Status Politics and the American Temperance Movement. University of Illinois Press.

Handman, Marie-Elisabeth and Janine Mossuz-Lavau, eds. 2005. La Prostitution à Paris. La Martinière: Paris.

Herzlich, Claudine, and Janine Pierret. 1988. "Une maladie dans l'espace public: le sida dans six quotidiens français." Annales ESC 43(5): 1109-1134. 
Jakšić, Milena. 2016. La traite des êtres humains en France. De la victime idéale à la victime coupable. Paris: CNRS éditions.

Jochim, Ashley E., and May, Peter J. 2010a. "Beyond Subsystems: Policy Regimes and Governance." The Policy Studies Journal 38(2): 303-327.

Journal Officiel de la République Française (JORF). (2002). Séance du 13 novembre 2002. Paris: Sénat.

Journal Officiel de la République Française (JORF). (2003). 2è séance du mardi 21 janvier. Paris: Assemblée nationale.

Journal Officiel de la République Française (JORF). (2013). 2è séance du 29 novembre 2013. Paris: Assemblée Nationale.

Kilvington, Judith, Sophie Day, and Helen Ward. 2001. "Prostitution in Europe: A Time of Change?" Feminist Review 67(1): 78-93.

Legro, Jeffrey W. 2000. "The transformation of policy ideas." American Journal of Political Science 44(3): 419-432.

Limoncelli, Stephanie A. 2006 "International Voluntary Associations, Local Social Movements and State Paths to the Abolition of Regulated Prostitution in Europe, 1875-1950." International Sociology 21(1): 31-59.

Mahoney, James, and Kathleen Thelen. 2010. "A theory of gradual institutional change." In Explaining Institutional Change: Ambiguity, Agency and Power, edited by James Mahoney and Kathleen Thelen, 103-126. New York, NY: Cambridge University Press.

Mainsant, Gwénaëlle. 2013. "Gérer les contradictions du droit "par le bas"." Actes de la recherche en sciences sociales 198(3): 23-34.

Mathieu, Lilian. 2000. Prostitution et Sida: Sociologie d'une épidémie et de sa prévention. Paris: L'Harmattan.

Mathieu, Lilian. 2001. Mobilisations de prostituées. Paris: Belin.

Mathieu, Lilian. 2004. "The Debate on Prostitution in France: A Conflict between Abolitionism, Regulation and Prohibition." Journal of Contemporary European Studies 12(2): 153-163.

Mathieu, Lilian. 2011. "Neighbors' anxieties against prostitutes' fears: Ambivalence and repression in the policing of street prostitution in France." Emotion, Space and Society 4: 113120.

Mathieu, Lilian. 2012. "An Ambiguous Compassion: Policing and Debating Prostitution in Contemporary France.” Sexuality Research \& Social Policy 9(3): 203-211.

Mathieu, Lilian. 2013a. La Fin du Tapin: Sociologie de la Croisade pour l'Abolition de la Prostitution. Lormont: Éditions François Bourin. 
Mathieu, Lilian. 2013b. "Génèse et Logiques des Politiques de Prostitution en France." Les Actes de la Recherche en Sciences Sociales 198(3): 5-20.

Mathieu, Lilian. 2014. "Invisibiliser et éloigner: Quelques tendances des politiques de la prostitution." Regards croisés sur l'économie 15(2): 290-301.

Maugère, Amélie. 2009. Les Politiques de la Prostitution: Du Moyen Age au XXIe siècle. Paris: Dalloz, Nouvelle Bibliothèque des Thèses Sciences Politiques.

May, Peter J., and Ashley E. Jochim. 2013. "Policy Regime Perspectives: Policies, Politics, and Governing." Policy Studies Journal 41(3): 426-452.

May, Peter J., Ashley E. Jochim, and Joshua Sapotichne. 2011. "Constructing Homeland Security: An Anemic Policy Regime." Policy Studies Journal 39(2): 285-307.

Mazur, Amy G. 2004. "Prostitute Movements Face Elite Apathy and Gender-Biased Universalism in France." In The Politics of Prostitution: Women's Movements, Democratic States and the Globalisation of Sex Commerce, edited by Joyce Outshoorn, 123-143. Cambridge: Cambridge University Press.

"Le plan anti-sida de la Ville de Paris - Mme Michèle Barzach se prononce pour la réouverture des maisons closes." Le Monde. 8 June 1990, 14.

"Les députés votent pour la pénalisation des clients de prostitués." Le Monde, 12 June 2015. Accessed 14 April 2015. http://www.lemonde.fr/societe/article/2015/06/12/prostitution-laproposition-de-loi-revient-a-l-assemblee-nationale_4652633_3224.html

Mossuz-Lavau, Janine. 2007. "Prostitution in Paris." In Prostitution and Public Life in Four European Capitals, edited by Daniela Danna,10-23. Rome: Carocci.

Pacione, Harmonie. 2014. "Prostitution: faut-il pénaliser les clients d'une amenda de 1500€?" La Dépêche, 13 July. Accessed 6 February 2015. http://www.ladepeche.fr/article/2014/07/13/1917898-prostitution-faut-penaliser-clientsamende-1500-e.html

Pinell, Patrice. 2002. "Introduction." In Une épidémie politique: la lutte contre le sida en France (1981-1996), edited by Patrice Pinel, 1-23. Paris: Presses Universitaires de France.

Pinot, Guy. 1975. Mission d'information sur la prostitution: rapport. Paris : Ministère de la condition feminine.

Plumauzille, Clyde. 2016. Prostitution et Révolution. Les femmes publiques dans la cité républicaine (1989-1804). Paris : Champ Vallon.

Pratt, Murray. 1998. "The defense of the straight state: heteronormativity, AIDS in France, and the space of the nation." French Cultural Studies 9(27): 263-280.

Roberts, Mary Louise. 2010. "The Silver Foxhole: The GIs and Prostitution in Paris, 19441945." French Historical Studies 33(1): 99-128. 
Rocco, Philip, and Chloe Thurston. 2014. "From metaphors to measures: Observable indicators of gradual institutional change." Journal of Public Policy 34(1): 35-62.

Schaffauser, Thierry. 2013. "La pénalisation contre-productive." Minorités, 3 November. Accessed on 27 July 2016. http://www.minorites.org/index.php/2-la-revue/1533-lapenalisation-contre-productive.html

Shpaizman, Ilana. 2014. "Ideas and institutional conversion through layering: The case of Israeli immigration policy." Public Administration 92(4): 1038-1053.

Skilbrei, May-Len, and Charlotta Holmström. 2011. "Is there a Nordic prostitution regime?" Crime and Justice 40: 479-518.

Solé, Jacques. 1993. L'Âge d'or de la prostitution de 1870 à nos jours. Paris: Librarie Plon.

Steffen, Monika. 1993. "AIDS policies in France.” In AIDS and Contemporary History, edited by Virginia Berridge and Philip Strong, 240-264. Cambridge; New York: Cambridge University Press.

Streeck, Wolfgang, and Kathleen Thelen. 2005. "Introduction." In Beyond continuity: Institutional Change in Advanced Political Economies, edited by Wolfgang Streeck and Kathleen Thelen, 1-57. Oxford: Oxford University Press.

Thelen, Kathleen. 2004. How Institutions Evolve: The Political Economy of Skills in Germany, Britain, the United States, and Japan. New York: Cambridge University Press.

Thiaudière, Claude, and Pierre Pinell. 2002. "Le temps de la 'non-intervention' (1982-1985)." In Une épidémie politique: La lutte contre le sida en France (1981-1996), edited by Patrice Pinel, 77-90. Paris: Presses Universitaires de France.

Thukral, Juhu. 2006. "Prohibition." In Encyclopedia of prostitution and sex work, Volume 1, edited by Melissa Hope Ditmore, 369. Westport, CT: Greenwood Press.

Vernier, Johanne. 2005. "La Loi pour la sécurité intérieure: punir les victimes du proxénétisme pour mieux les protéger?". In ), La Prostitution à Paris, edited by Marie-Elisabeth Handman and Janine Mossuz-Lavau, 121-152. Paris: Éditions de la Martinière.

Vogel, Stephen K. 2005. "Routine Adjustment and Bounded Innovation: The changing political economy of Japan." In Beyond Continuity: Institutional change in advanced political economies, edited by Wolfgang Streeck and Kathleen Thelen, pp. 145-168. Oxford; New York: Oxford University Press. 